\title{
Doskonalenie potencjału instytucjonalnego w jednostkach publicznych na przykładzie urzędów gmin miejskich województwa podkarpackiego
}

\section{Streszczenie}

W ostatnich latach można zauważyć wzrost znaczenia badań nad doskonaleniem potencjalnej sprawności funkcjonowania i zarządzania instytucjami samorządowymi. Sprawnie działająca administracja samorządowa jest jednym z podstawowych czynników wpływających na jakość życia mieszkańców. Celem artykułu jest ocena poziomu rozwoju i struktury potencjału instytucjonalnego urzędów gmin miejskich w woj. podkarpackim w 2014 i 2019 roku. W artykule wykorzystano metodykę Analizy Instytucjonalnej przygotowaną przez Małopolską Szkołę Administracji Publicznej Akademii Ekonomicznej w Krakowie. Wyniki badań pokazują niski poziom rozwoju potencjału instytucjonalnego badanych urzędów gmin miejskich w obu analizowanych latach. Najkorzystniejsza sytuacja występowała w następujących obszarach: organizacji i funkcjonowania urzędu, partycypacji społecznej i stymulowania rozwoju społecznego oraz współpracy między jednostkami samorządu terytorialnego.

W odniesieniu do przyszłych badań zaprezentowana w artykule metodologia, wraz z uzyskanymi wynikami, może się przyczynić się do dokonywania podobnych analiz w przyszłości, a także stanowić przedmiot zainteresowania badań poznawczych i wdrożeniowych.

Słowa kluczowe: administracja publiczna, urząd miasta, potencjał instytucjonalny

Kody klasyfikacji JEL: H11, H50, H83

DOI: $10.33119 / \mathrm{KSzPP} / 2020.3 .5$

1 Uniwersytet Rzeszowski, Kolegium Nauk Społecznych, Instytut Ekonomii i Finansów, e-mail: mgrzebyk6@gmail.com, https://orcid.org/0000-0003-1107-0250 


\title{
Improving the institutional potential in public units based on the example of municipal offices of Podkarpackie Voivodeship
}

\begin{abstract}
In the recent years, there has been an increase in the importance of research on improving the potential efficiency of functioning and managing local government institutions. Efficiently functioning local government administration is one of the basic factors influencing the quality of residents' life. The purpose of the article is to assess the development level and structure of institutional potential of municipal offices in Podkarpackie Voivodeship in 2014 and 2019. The article uses the Institutional Analysis methodology prepared by the Małopolska School of Public Administration of the Cracow University of Economics. The research results showed a low level of institutional potential development of the surveyed municipal offices in both analyzed years. The most favorable situation can be observed in the following areas: organization and functioning of the office, social participation, and social development stimulation, as well as cooperation between territorial self-government units. In respect to future research, the methodology presented in the article, together with the results obtained can be contributory to a similar analysis in the future and serve as the subject of interest for cognitive and implementation research studies as well.
\end{abstract}

Keywords: public administration, municipal office, institutional potential

JEL Classification Codes: H11, H50, H83

W obecnych czasach jednostki samorządu terytorialnego, podobnie jak inne organizacje, działają w warunkach szybko zmieniającego się i trudnego do przewidzenia otoczenia (Narbón-Perpiñá, De Witte, 2018a; Žurga, 2018). To otoczenie tworzy uwarunkowania zewnętrzne w postaci zestawu szans i zagrożeń, które wspierają lub utrudniają rozwój. Gmina jako samorządowa wspólnota mieszkańców jest podstawową formą organizacyjną lokalnego życia publicznego w Polsce. Jej głównym zadaniem jest zaspokajanie zbiorowych potrzeb lokalnej wspólnoty, czyli tworzenie jak najlepszego środowiska życia mieszkańców (Grzebyk, 2017).

Jednostkami pomocniczymi gminy są urzędy gmin, a przedmiotem ich działalności jest obsługa administracyjna organów gminy i środowiska lokalnego. Działają według określonych ustawami ram prawnych, które wyznaczają ich zadania i obowiązki. Akty wykonawcze opisują procedury, które są stosowane w procesie realizacji celów (Pierścieniak et al., 2018). 
Wiele badań i opracowań dotyczących zmian w funkcjonowaniu urzędów gmin było prowadzonych w Polsce w latach 2000-2015². Związane one były w szczególności z wprowadzaniem zasad dobrego rządzenia w instytucjach Unii Europejskiej (UE). Komisja Europejska za pośrednictwem funduszy UE wspierała działania związane nie tylko $\mathrm{z}$ upowszechnianiem wiedzy na temat zasad dobrego rządzenia czy formułowaniem wytycznych poprawy jakości rządzenia, ale przede wszystkim finansowała badania i projekty związane z opracowaniem metodyk i narzędzi, które pozwalały na ocenę stanu rozwoju instytucjonalnego czy poprawę jakości funkcjonowania urzędów publicznych ${ }^{3}$.

Jedną z wiodących metodyk powstałych w 2000 roku, a opracowanych w ramach UE, jest CAF (Common Assessment Framework), czyli Powszechny Model Oceny. Jest narzędziem kompleksowego zarządzania jakością przeznaczonym dla jednostek administracji publicznej. Metoda CAF skupia się na przeprowadzeniu samooceny, identyfikacji obszarów doskonalenia oraz wprowadzaniu wymaganych usprawnień zarządczych. Jest to model całościowego przeglądu funkcjonowania instytucji, z uwzględnieniem analizy wyników jej działalności oraz potencjału organizacyjnego (CAF w samorzadzie..., 2010).

Metoda ta wykorzystuje podział na dwa główne obszary (kryteria potencjału i kryteria wyników). Na obszar potencjału składa się pięć kryteriów, a na obszar wyników - cztery. Do kryteriów potencjału zalicza się kwestie takie, jak: przywództwo, pracownicy, strategia i planowanie, partnerstwo i zasoby oraz procesy. Natomiast do zakresu kryteriów, w odniesieniu do wyników, zaliczamy: wyniki działalności w relacjach z pracownikami, wyniki działalności w relacjach $\mathrm{z}$ obywatelami, społeczne wyniki działalności oraz kluczowe wyniki działalności. Każde kryterium składa się z podkryteriów. Jest ich łącznie 28 i określają one kwestie, jakie należy rozpatrzyć przy ocenie danej organizacji. Metoda CAF jako instrument kompleksowego zarządzania jakością opiera się na podstawowych pojęciach związanych z ideą doskonałości, a więc: orientacji na wyniki, orientacji na klienta, przywództwie i stałości celów, zarządzaniu poprzez procesy i fakty, zaangażowaniu i rozwoju pracowników, ciągłym

2 W kolejnych okresach programowania podejmowano inicjatywy rządowe takie jak Program Rozwoju Instytucjonalnego zapoczątkowany w roku 2001 w ramach Programu Aktywizacji Obszarów Wiejskich oraz w ramach programów operacyjnych ukierunkowano priorytety na poprawę funkcjonowania administracji publicznej np. w ramach Programu Operacyjnego Kapitał Ludzki w latach 2007-2013 realizowano priorytet V - Dobre Rządzenie.

3 W ramach usprawniania pracy urzędu opracowano kilka metodyk i narzędzi do oceny jakości zarządzania w instytucjach publicznych, m.in. w 2000 r. wspólna metoda oceny CAF zainspirowana Modelem Doskonałości Europejskiej Fundacji Zarządzania Jakością (EFQM) czy opracowana w Polsce w roku 2004 metodyka Analizy Rozwoju Instytucjonalnego przygotowana w ramach Programu Rozwoju Instytucjonalnego i później doskonalona. Zob. Żabiński (2012: 57-76). 
doskonaleniu i wprowadzaniu innowacji, rozwoju partnerskich stosunków z kontrahentami oraz poczuciu społecznej odpowiedzialności (Łuczak, Wolniak, 2013).

Inną interesującą metodyką jest Analiza Instytucjonalna (AI) przygotowana w ramach projektu „Program Rozwoju Instytucjonalnego” (PRI), realizowanego przez Konsorcjum Canadian Urban Institute i Małopolską Szkołę Administracji Publicznej Akademii Ekonomicznej w Krakowie na zlecenie Ministerstwa Spraw Wewnętrznych i Administracji (MSWiA). Zwraca się w niej uwagę na kształtowanie odpowiednich struktur organizacyjnych, właściwe procedury działania, mechanizmy zapewniające udział społeczności lokalnej w zarządzaniu sprawami publicznymi oraz kompetentnych i sprawnych urzędników. PRI wpisuje się w nurt budowania nowoczesnej administracji publicznej według koncepcji good governance (Zawicki, Mazur, 2004).

W świetle tych rozważań celem artykułu jest ocena poziomu rozwoju i struktury potencjału instytucjonalnego urzędów gmin miejskich w woj. podkarpackim w 2014 i 2019 roku. Wykorzystano w badaniach jedną z zaprezentowanych metod - Analizę Instytucjonalną. Realizacja tego celu wymagała podzielenia artykułu na kilka części. Na początku przedstawiono pojęcie i strukturę potencjału instytucjonalnego urzędu gminy, z charakterystyką poszczególnych obszarów zastosowanej metody. $\mathrm{Na}$ tym tle dokonano analizy uzyskanych wyników, aby w podsumowaniu zaprezentować wyniki badań i ich znaczenie praktyczne. Zakres przestrzenny badań obejmuje 12 gmin miejskich położonych na terenie woj. podkarpackiego.

Uzyskane w ten sposób informacje dotyczące poziomu zarządzania w urzędach gmin mają znaczenie praktyczne. Ułatwią władzom lokalnym dokonanie realnej oceny ich funkcjonowania, mogą pomóc w udoskonaleniu, poprawie czy podnoszeniu sprawności i efektywności działalności tych urzędów gmin.

\section{Pojęcie i struktura potencjału instytucjonalnego urzędu gminy}

Urząd gminy jest jednostką organizacyjną realizującą z jednej strony obsługę administracyjno-biurową organów gminy, $z$ drugiej załatwianie spraw obywateli gminy. Pracownicy urzędu zapewniają przygotowanie i wykonanie rozstrzygnięć podejmowanych przez organy, które urząd obsługuje, jak również mogą uzyskać prawo do wydawania, $\mathrm{z}$ upoważnienia organu (w gminie jednoosobowego organu wykonawczego) i w jego imieniu, decyzji w indywidualnych sprawach z zakresu administracji publicznej (art. 39 ust. 1 ustawy gminnej). Ponadto mogą oni uzyskać pełnomocnictwa do reprezentowania danej jednostki samorządu w obrocie 
cywilnoprawnym na zasadach i w trybie określonym w poszczególnych podstawowych ustawach ustrojowych (Grzebyk, 2014; Izdebski, 2008).

W literaturze przedmiotu pojęcie potencjału instytucjonalnego jednostki administracji publicznej najczęściej definiuje się w sposób opisowy, uwzględniający różne obszary funkcjonowania urzędu, wskazując na jego pewne cechy, m.in. (Beeri, 2012; Lapsley, 2001; Mazur, 2004; Rodriguez-Pose, 2013):

- zdolność do zarządzania strategicznego,

- struktury organizacyjne oraz procedury działania służące realizacji celów strategicznych,

- efektywne mechanizmy zarządzania zasobami ludzkimi,

- świadczenie usług publicznych opartych na odpowiednich standardach i ocenie kosztów,

- sprawny system komunikacji ze społecznością lokalną i mechanizmy jej angażowania w zarządzanie sprawami lokalnymi,

- umiejętność tworzenia ram i warunków do wspierania lokalnej przedsiębiorczości,

- przejrzyste procedury działania.

Podobnie potencjał instytucjonalny definiują Bhagaran i Virgin (2004), określając go jako możliwości wykonywania funkcji i zadań przez organizację publiczną z wykorzystaniem posiadanych zasobów (ludzkich, finansowych, technicznych i informacyjnych) oraz struktury potrzebne do ich wykonywania.

Przyjęta w artykule definicja potencjału instytucjonalnego urzędu gminy została określona jako konfiguracja możliwości oraz zdolności urzędu do realizacji nałożonych nań zadań, zawarta w posiadanych przez ten urząd zasobach i umiejętnym ich wykorzystaniu w celu osiągnięcia jak najwyższej sprawności.

Najlepiej tej definicji odpowiadają obszary zarządzania wchodzące w skład Analizy Instytucjonalnej urzędu gminy, stąd takie podejście zostało tutaj wykorzystane. Analiza ta obejmuje różne obszary zarządzania i funkcjonowania urzędu, które mogą zostać wykorzystane do podniesienia sprawności funkcjonowania tego typu organizacji (Grzebyk, Pierścieniak, 2015). Potencjał instytucjonalny urzędu gminy obejmuje wymienione w AI obszary zarządzania jako jego składowe, do których zaliczono: zarządzanie strategiczne i finansowe (1), organizację i funkcjonowanie urzędu (2), zarządzanie kadrami (3), usługi publiczne, w tym komunalne (4), partycypację społeczną i stymulowanie rozwoju (5), stymulowanie rozwoju gospodarczego (6), zarządzanie projektami (7), współpracę między jednostkami samorządu terytorialnego (8) oraz etykę i zapobieganie zjawiskom korupcji (9). Poszczególne obszary zarządzania i składające się na nie kryteria zarządzania zaprezentowano w tabeli 1.

Vademecum Analiza Instytucjonalna Urzędu Gminy opracowano z zamiarem wdrożenia projektu PRI. Zgodnie z poglądem leżącym u podstaw PRI istotną 
determinantą rozwoju poszczególnych jednostek gminnych i powiatowych jest administracja samorządowa, która podejmuje inicjatywę i przyczynia się znacząco swoim działaniem do unowocześnienia, a zarazem usprawnienia funkcjonowania gminy czy też powiatu. Takie postępowanie, mające na celu modernizację wspomnianych jednostek samorządu terytorialnego, administracja samorządowa traktuje często jako priorytet w swojej działalności (Grzebyk, Pierścieniak, 2014).

Tabela 1. Obszary i kryteria zarządzania brane pod uwagę w Analizie Instytucjonalnej urzędu gminy

\begin{tabular}{|c|c|}
\hline Obszary zarządzania urzędem & Kryteria zarządzania \\
\hline $\begin{array}{l}\text { 1. Zarządzanie strategiczne } \\
\text { i finansowe }\end{array}$ & $\begin{array}{l}\text { 1. Planowanie strategiczne } \\
\text { 2. Perspektywiczna ocena sytuacji finansowej } \\
\text { 3. Wieloletnie planowanie inwestycyjne } \\
\text { 4. Roczne planowanie finansowe, monitorowanie i ocena wykonania planów }\end{array}$ \\
\hline $\begin{array}{l}\text { 2. Organizacja i funkcjonowanie } \\
\text { urzędu }\end{array}$ & $\begin{array}{l}\text { 5. Podział uprawnień decyzyjnych i odpowiedzialności } \\
\text { 6. Zarządzanie procesami } \\
\text { 7. Efektywność komunikacji wewnętrznej }\end{array}$ \\
\hline 3. Zarządzanie kadrami & $\begin{array}{l}\text { 8. System rekrutacji personelu } \\
\text { 9. System oceny i awansowania pracowników } \\
\text { 10. System szkoleń i doskonalenia zawodowego }\end{array}$ \\
\hline 4. Usługi publiczne, w tym komunalne & $\begin{array}{l}\text { 11. Standardy świadczenia usług publicznych } \\
\text { 12. Planowanie świadczenia usług publicznych } \\
\text { 13. Doskonalenie świadczenia usług publicznych }\end{array}$ \\
\hline $\begin{array}{l}\text { 5. Partycypacja społeczna } \\
\text { i stymulowanie rozwoju } \\
\text { społecznego }\end{array}$ & $\begin{array}{l}\text { 14. Komunikacja i partycypacja społeczna } \\
\text { 15. Współpraca z organizacjami pozarządowymi } \\
\text { 16. Wspieranie inicjatyw społecznych }\end{array}$ \\
\hline $\begin{array}{l}\text { 6. Stymulowanie rozwoju } \\
\text { gospodarczego }\end{array}$ & 17. Program rozwoju gospodarczego \\
\hline 7. Zarządzanie projektami & 18. System zarządzania projektami \\
\hline $\begin{array}{l}\text { 8. Współpraca między jednostkami } \\
\text { samorządu terytorialnego }\end{array}$ & $\begin{array}{l}\text { 19. Realizowanie przedsięwzięć we współpracy z innymi jednostkami } \\
\text { samorządu terytorialnego }\end{array}$ \\
\hline 9. Etyka i zapobieganie korupcji & 20. Ksztattowanie postaw etycznych \\
\hline
\end{tabular}

Źródło: Mazur (2004: 48); Truskolaski (2010: 37).

Ponadto AI służy jako przydatne kompendium do rozpoznania poziomu rozwoju instytucjonalnego. Pozwala też określić, jakie modyfikacje są niezbędne w danym obszarze działania urzędu, aby funkcjonował on prawidłowo i efektywnie. Urząd gminy jest bowiem organizacją, u podstaw której leży polepszenie jakości życia mieszkańców i dążenie do rozwoju lokalnego pożądanego przez grupy społeczne zamieszkujące określone terytorium (Kusto, 2019). 
Stopień rozwoju ${ }^{4}$ wszystkich obszarów działania urzędu administracji lokalnej jest określany w AI za pomocą pięciostopniowej skali i nawiązuje do oceny narzędzi zarządzania wykorzystywanych w danym obszarze funkcjonowania urzędu. Kryteria zarządzania właściwe dla określonego obszaru służą dokonaniu oceny danego stadium rozwoju. Przyjmuje się, że pierwsze stadium rozwoju (1) jest najniższe i bez większych starań osiąga je każdy urząd. Eksperci odpowiedzialni za opracowanie Analizy Instytucjonalnej Urzędu Gminy kierowali się przekonaniem, że urząd, osiągając to stadium rozwoju, nie korzysta w swojej działalności z narzędzi zarządzania charakterystycznych dla konkretnego obszaru albo posługuje się nimi w niewielkim stopniu. Kolejne stadia, czyli 2, 3 i 4, wyrażają poszczególne fazy rozwoju, które sukcesywnie przechodzą od fazy formalistycznej, zadaniowej, poprzez etap procedur, a następnie fazę aktywnego uczestnictwa (społecznego lub pracowniczego w stosunku do kryteriów). Ostatnie już, 5 stadium, najtrudniejsze do osiągnięcia, stanowi ideał działania instytucji, który powinien być wzorem dla innych urzędów. W stadium tym kluczową funkcję pełnią procesy samodoskonalenia, czyli świadomego i zamierzonego koordynowania i unowocześniania wykorzystywanych przez urząd narzędzi zarządzania. Każde następne stadium oprócz 1 jest coraz trudniej osiągalne dla urzędu, bowiem wymaga dużego zaangażowania w działanie. Stadia 2-5 odzwierciedlają również przypuszczalny sposób osiągania rozwoju instytucjonalnego przez dany urząd. Kryteria zarządzania zostały sporządzone zgodnie z zasadą kumulacji, co oznacza, że przejście do kolejnego, a zatem wyższego stadium rozwoju stwarza konieczność spełnienia wszystkich warunków dla tego stadium, jak również wszystkich warunków sprecyzowanych dla stadium poprzedniego. Tylko stadium 1 stanowi wyjątek, ponieważ założono, że jest ono możliwe do osiągnięcia dla wszystkich urzędów (Zawicki, Mazur, 2004).

Podkreślając zalety tej metody, nie należy zapominać także o jej mankamentach. Opracowana w latach 2001-2004 do samooceny sprawności zarządzania głównie gmin wiejskich opiera się na kryteriach, które mogą nie pasować do aktualnej sytuacji jednostek samorządu terytorialnego. Jak wiadomo kryteria oceny jakościowej są zmienne w czasie i to powinno być uwzględnione przy kolejnej modyfikacji tej metody. Podkreśla się także, że metoda ta, opierając się na autodiagnozie, nie jest zbyt zobiektywizowana.

Pomimo swojej słabości jest jedną z nielicznych metod pozwalających na określenie poziomu rozwoju poszczególnych obszarów zarządzania JST w sposób prosty i czytelny.

\footnotetext{
4 Pojęcia „stopień rozwoju”, „stadium” czy „poziom rozwoju” są w artykule używane zamiennie.
} 


\section{Analiza wyników badań}

Województwo podkarpackie leży w południowo-wschodniej części kraju. Od wschodu graniczy z Ukrainą, a od południa ze Słowacją. Pod względem administracyjnym dzieli się na 160 gmin, obejmując 110 gmin wiejskich, 34 gminy miejsko-wiejskie i 16 gmin miejskich, w tym cztery miasta na prawach powiatu (Rzeszów, Krosno, Tarnobrzeg i Przemyśl).

Badania przeprowadzono w latach 2014 i 2019 w 12 urzędach gmin miejskich, wyłączając miasta na prawach powiatu. Miasta te nie zostały wzięte pod uwagę, bowiem charakteryzują się znacznie wyższym poziomem rozwoju społeczno-gospodarczego (do reformy administracyjnej Polski z roku 1998 były stolicami województw) niż pozostałe gminy, realizują również zadania właściwe dla jednostek powiatowych. Do określenia poziomu rozwoju potencjału instytucjonalnego danego urzędu posłużyły kwestionariusze diagnostyczne ${ }^{5}$, które zawierają kompletne zestawienia warunków wymaganych dla każdego stadium. Kwestionariusz ten zawiera pytania o fakty, działania, dokumenty znajdujące się w urzędzie, nie pytano o opinie ani nie wyrażano ocen subiektywnych. Nadmienić należy, że wypełnienie kwestionariusza było czasochłonne, dlatego często dzielono go na części, które uzupełniały osoby kompetentne zatrudnione w urzędzie, przypisane do danego obszaru.

Ocena wszystkich dziewięciu obszarów zarządzania i dwudziestu kryteriów składających się na te obszary została zaprezentowana w tabeli 2. Ogólny poziom potencjału instytucjonalnego badanych urzędów gmin został określony jako średni poziom rozwoju poszczególnych obszarów zarządzania (od 1 do 9) i ich kryteriów (od 1 do 20).

Analizując dane tej tabeli, można zauważyć, że średni wskaźnik dla wszystkich badanych urzędów gmin miejskich wyniósł w 2019 roku 2,4, wobec 2,1 w 2014 roku. Oznacza to, że nie jest on wysoki, osiągając wartość poniżej 3 (z pięciostopniowej skali) w obu analizowanych latach. Dokonując bardziej szczegółowej analizy, czyli oceniając poszczególne obszary zarządzania urzędem gminy, stwierdza się, że w 2014 roku nie ma obszaru zarządzania osiągającego stadium wyższe niż 2. Porównując jednak 2014 i 2019 rok, zauważa się wzrost poziomu rozwoju potencjału instytucjonalnego w 2019 roku w zakresie obszaru II, V i VIII ze stadium 2 do 3.

5 Kwestionariusz diagnostyczny posłużył do oceny poziomu rozwoju potencjału instytucjonalnego poprzez weryfikację warunków określonych dla każdego stadium rozwoju w ramach danego obszaru zarządzania. Warunki te zostały tak sformułowane, aby możliwy był wybór jednoznacznych odpowiedzi TAK lub NIE. Kwestionariusz ten jest dostępny na stronie internetowej: http://www.msap.uek.krakow. pl/doki/publ/pri_aiug.pdf 
W ramach Organizacji i funkcjonowania urzędu (obszar nr 2) wyróżnia się trzy kryteria zarządzania: Podział uprawnień decyzyjnych i odpowiedzialności (nr 5), Zarządzanie procesami (nr 6) i Efektywność komunikacji wewnętrznej (nr 7). Podział uprawnień decyzyjnych i odpowiedzialności to piąte spośród 20 kryteriów wyróżnionych w Analizie Instytucjonalnej. W jego ramach (idąc od najniższego stadium rozwoju) zostały zidentyfikowane i przypisane szczegółowe zakresy uprawnień decyzyjnych radzie, wójtowi i kierownikom referatów oraz sformułowane zasady monitorowania i oceny urzędu pod kątem poszukiwania, nakładania się kompetencji i zadań oraz ich aktualizowania. W przypadku tego kryterium poziom rozwoju osiągnął stadium 3 i nie zmienił się w badanych latach. Szczegółowa analiza kwestionariuszy diagnostycznych pozwala stwierdzić, że urzędy gmin właściwie podzieliły uprawnienia decyzyjne, w tym zadania, uprawnienia i odpowiedzialność, między poszczególne elementy struktury organizacyjnej urzędu, ale niestety nie ma w większości przypadków zasad monitorowania i oceny pracy urzędu, zwłaszcza pod kątem nakładania się kompetencji i zadań poszczególnych stanowisk pracy czy komórek organizacyjnych.

W zakresie kryterium Zarządzania procesami w urzędzie gminy zostały zidentyfikowane najważniejsze dla tego urzędu procesy oraz wyłoniono osoby odpowiedzialne za ich prawidłowy przebieg (stadium 2 i 3). Wybrane procesy są wspomagane komputerowo, a ich realizacja jest monitorowana, oceniana i doskonalona (stadium 4 i 5). Osiągnięcie stadium 3 w 2019 roku w zakresie Zarządzania procesami wiąże się z identyfikowaniem procesów i przypisaniem szczegółowych zakresów uprawnień decyzyjnych kierownikom w urzędzie. Brak jednak w urzędach szczegółowych regulacji wewnętrznych. W wielu przypadkach procesy te nie są wspomagane komputerowo, monitorowane czy doskonalone.

Ważnym elementem funkcjonowania urzędu gminy jest także Efektywność komunikacji wewnętrznej, rozumiana jako niezbędne przepływy informacyjno-decyzyjne umożliwiające realizację procedur i sprawną koordynację. Uwzględnia ono zarówno komunikację poziomą (przepływ informacji między stanowiskami czy komórkami wykonującymi te same lub podobne zadania), jak i komunikację pionową (przepływ informacji z góry do dołu - od kierowników do szczebli niższych lub odwrotnie). Tutaj, podobnie jak w przypadku poprzedniego kryterium, stadium rozwoju zmieniło się w badanych latach z 2 na 3. Oznacza to, że istnieją i są stosowane zasady określające wymianę informacji między organem wykonawczym a uchwałodawczym, ale nie dotyczy to pracy całego urzędu jako jednostki organizacyjnej.

Kolejnym obszarem, w którym nastąpił wzrost stadium rozwoju z 2 do 3, jest Partycypacja społeczna i stymulowanie rozwoju społecznego (nr 5). Według PRI jest ona rozumiana jako włączanie organizacji pozarządowych, lokalnego biznesu oraz inicjatyw społecznych w rozwiązywanie problemów lokalnych i podejmowanie 
kluczowych decyzji dotyczących wspólnoty lokalnej. Partycypacja społeczna jest nierozerwalnie związana $\mathrm{z}$ komunikacją społeczną, stanowi wyższą w stosunku do komunikowania formę współpracy władz publicznych z mieszkańcami oraz ich organizacjami. W tym obszarze wyzwaniami dla urzędu są (Zawicki, Mazur, 2004):

- zapewnienie skutecznej komunikacji dwustronnej pomiędzy urzędem a obywatelem i odwrotnie,

- kształtowanie zinstytucjonalizowanej współpracy trójstronnej między samorządem terytorialnym, organizacjami pozarządowymi oraz lokalnym biznesem,

- wspieranie organizacji pozarządowych oraz grup obywatelskich w realizacji celów ważnych dla lokalnej wspólnoty.

Ten obszar zarządzania obejmuje także trzy kryteria: Komunikację i partycypację społeczną (nr 14), Współpracę z organizacjami pozarządowymi (nr 15) oraz Wspieranie inicjatyw społecznych (nr 16). W obrębie kryterium Komunikacja i partycypacja społeczna są spełnione warunki tylko dla stadium 2 . Analiza wypełnionych kwestionariuszy pokazuje, że urzędy gmin miejskich informują mieszkańców o ważnych dla nich sprawach przy pomocy dostępnych narzędzi przekazu informacji, ale w wielu przypadkach nie dokonują oceny efektywności i skuteczności ich stosowania. Najczęściej wymienianymi narzędziami są: katalog usług urzędu, tablice i gabloty informacyjne, punkt informacyjny w urzędzie, strona www, biuletyn urzędu, gazeta lokalna oraz współpraca z mediami.

W obrębie tego obszaru wysoko zostało ocenione kryterium Współpraca z organizacjami pozarządowymi (zmiana stadium rozwoju z 3 na 4). Jest to zarazem to kryterium, które osiągnęło najwyższy poziom rozwoju ze wszystkich analizowanych. Oznacza to, że współpraca ta ma charakter ciągły, a nie doraźny. Jest też w wielu gminach opracowany program takiej współpracy. Niestety nie jest on monitorowany ani uaktualniany.

Kolejnym ważnym kryterium dla sprawnego funkcjonowania urzędu gminy jest Wspieranie inicjatyw społecznych (zmiana stadium rozwoju z 2 na 3). W urzędach zidentyfikowano obszary takiego wsparcia w formie dofinansowania przedsięwzięć, zakupów bezpośrednich czy pomocy organizacyjnej. Pomoc jest udzielana na wniosek, z wykorzystaniem odpowiednich formularzy. Opracowano tryb, zasady czy kryteria oceniania wniosków i udzielania takiej pomocy. Nie dokonuje się jednak monitorowania i uaktualniania oceny funkcjonowania systemu wspierania inicjatyw społecznych w tych urzędach gmin.

Ostatnim obszarem, w którym nastąpiła zmiana stadium rozwoju z 2 na 3, jest Współpraca między jednostkami samorządu terytorialnego (nr 8). Obejmuje on tylko jedno kryterium - Realizację przedsięwzięć we współpracy z innymi jednostkami samorządu terytorialnego (nr 19). Według PRI współpraca między jednostkami 
samorządu terytorialnego jest rozumiana jako inicjowanie, planowanie i realizacja przedsięwzięć we współdziałaniu z innymi jednostkami samorządu (Zawicki, Mazur, 2004). Może się odbywać na płaszczyźnie gospodarczej i społecznej w postaci realizacji wspólnych przedsięwzięć społeczno-gospodarczych, w sferze usług publicznych, np. poprzez wspólne świadczenie usług komunalnych czy administracyjnych, w obszarze zarządzania projektami w postaci wspólnego ubiegania się o środki pomocowe na realizację różnego rodzaju przedsięwzięć ważnych dla współpracujących jednostek. Jest traktowana jako sposób doskonalenia zarządzania i rozwiązywania problemów lokalnych i regionalnych. Analiza kwestionariuszy diagnostycznych pokazuje, że wiele urzędów gmin miejskich takie inicjatywy podejmuje, ale nie uwzględnia środków finansowych w budżecie roku bieżącego na te cele.

Należy jeszcze zaznaczyć, że w obrębie obszaru 4, czyli Świadczenia usług publicznych, zmianie uległo kryterium Planowanie świadczenia usług publicznych (nr 12) ze stadium 2 na 3. Nie wpłynęło to jednak na wzrost ogólnego wskaźnika poziomu rozwoju tego obszaru. Wynika to z tego, że pozostałe dwa kryteria składające się na ten obszar, czyli Standardy świadczenia usług publicznych (nr 11) oraz Doskonalenie świadczenia tych usług (nr 13), nie zmieniły swojego poziomu rozwoju. Planowanie usług polega na analizie i prognozie potrzeb oraz możliwości ich realizacji, nastawione jest na ciągłe podnoszenie jakości i racjonalizację ich wykonywania. W odniesieniu do tego kryterium stwierdza się, że są opracowywane katalogi usług oraz schematy ich organizacji i dostarczania, ale nie dla wszystkich usług realizowanych przez gminy.

Osiągnięty poziom rozwoju wszystkich 20 kryteriów składających się na potencjał instytucjonalny wszystkich badanych urzędów gmin miejskich pokazuje rysunek 1. Prezentuje on koło o promieniu 5, czyli stadia rozwoju (od 1 do 5) możliwe do uzyskania przez badane urzędy gmin. Stadium 5 to tzw. stadium doskonałości instytucjonalnej, bardzo trudne do osiągnięcia. Obszar zacieniony został wyznaczony przez rzeczywiste wartości wszystkich 20 kryteriów zarządzania i obejmuje tylko ok. 30\% powierzchni maksymalnej. To pokazuje bardzo niski poziom poszczególnych kryteriów zarządzania. 


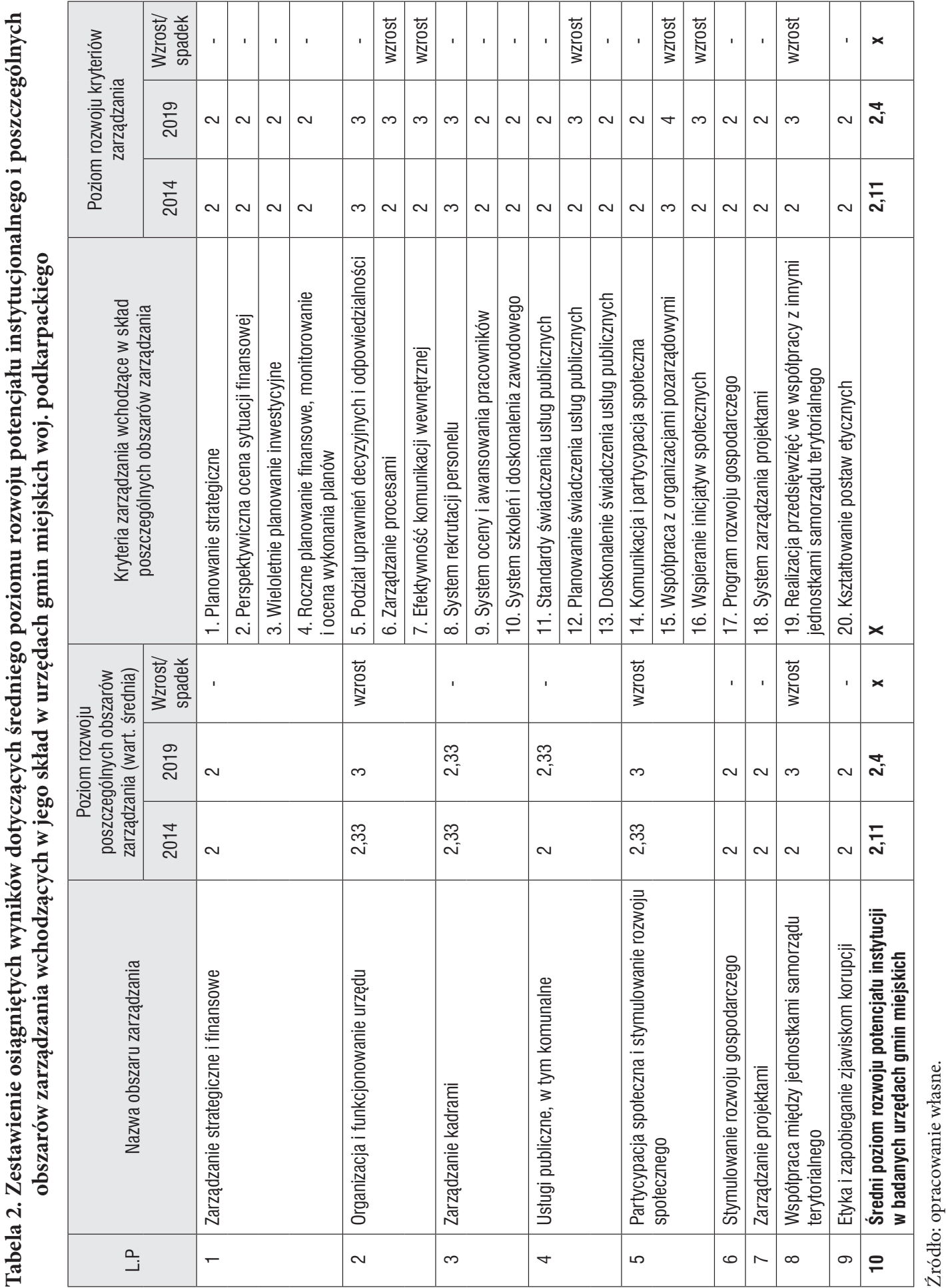




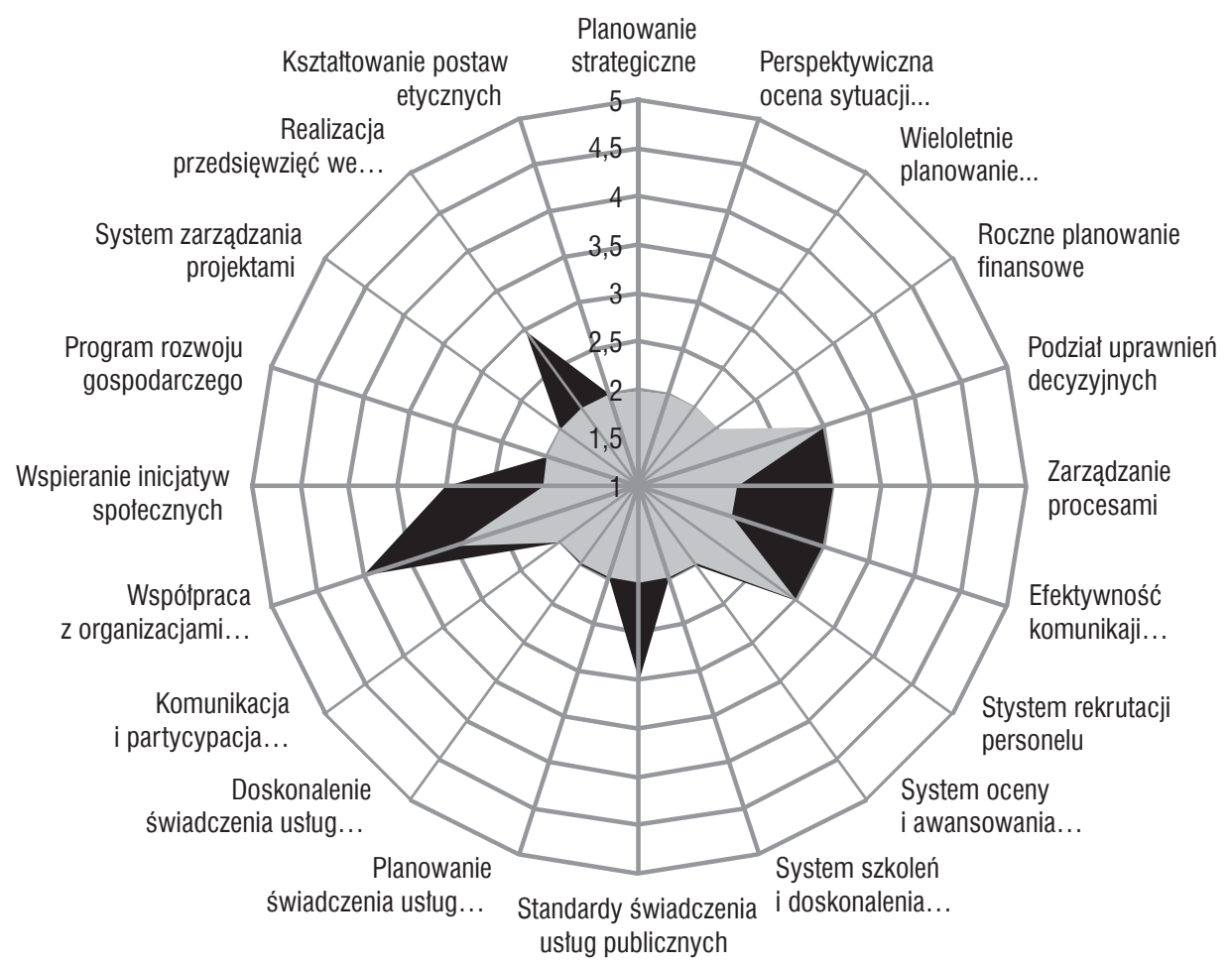

$2019 \quad 2014$

Rysunek 1. Poziom rozwoju poszczególnych kryteriów zarządzania składających się na potencjał instytucjonalny urzędów gmin w roku 2014 i 2019

Źródło: opracowanie własne.

Instytucją odpowiedzialną za przebieg procesów rozwojowych w gminie jest administracja gminna. Obecnie przed administracją samorządową stoją duże wyzwania, których podłożem są przemiany ustrojowe, gospodarcze czy społeczne. Administracja samorządowa powinna wprowadzać zmiany w sposób ciągły, dostosowując się także do modyfikacji otoczenia. Stąd rosnący popyt na wiedzę, rozwiązania, metody i techniki, czyli wszystko to, co może być użyteczne w przypadku doskonalenia funkcjonowania jednostki samorządu terytorialnego (Narbón-Perpiñá, De Witte, 2018b).

Urząd gminy, prowadząc stały monitoring tego, co się w gminie dzieje, staje się odpowiedzialny za rozwój podległego mu terytorium (Pierścieniak, Grzebyk, 2015). Analiza potencjału instytucjonalnego urzędu gminy i jego obszarów pozwala na zwrócenie uwagi na determinanty sprawności funkcjonowania tego typu organizacji, czyli te obszary zarządzania, które stanowią tzw. wąskie gardła, wymagające wprowadzania zmian w ich działalności. 
Wyniki badań pokazują, że dużych zmian należy dokonać praktycznie we wszystkich obszarach potencjału instytucjonalnego. Niektóre tylko spośród nich osiągnęły trzecie stadium rozwoju na pięć poziomów możliwych do uzyskania. Wprowadzanie zmian w tych obszarach może posłużyć do doskonalenia procesu zarządzania, poprawy efektywności działania czy lepszego wypełniania zadań przez urzędy gmin, w tym pełnienia misji.

Współcześnie w dobie rosnącej konkurencji między jednostkami terytorialnymi zasadne wydaje się prowadzenie badań i analiz w tym zakresie. Należy pamiętać, że jednym z kluczowych czynników służących rozwojowi wspólnot lokalnych staje się sprawna i efektywna administracja samorządowa, inicjująca i wspierająca działania na rzecz poprawy jakości życia mieszkańców oraz rozwoju lokalnego (Stuglik, 2016).

Ponadto uzyskane wyniki pozwolą ocenić miejsce danego urzędu gminy na tle innych jednostek tego samego szczebla, czyli porównać poziom zarządzania w poszczególnych jednostkach samorządowych i mogą się stać podstawą usprawniania prowadzonej polityki lokalnej przez władze samorządowe, wprowadzania odpowiednich zmian, w tym instytucjonalnych. Mogą mieć przełożenie na przygotowanie odpowiednich programów i działań o charakterze strategicznym poprzez wykorzystanie doświadczeń i dobrych praktyk zarządzania urzędem gminy jako całością organizacyjną, jak i poszczególnymi jej komponentami.

\section{Bibliografia}

Beeri, I. (2012). Turnaround Management Strategies in Local Authorities: Not Only for Poor Performers, Local Government Studies, 38(4): 461-483.

Bhagaran, M.R., Virgin, I. (2004). Generic aspects of institutional capacity development in development countries, Stockholm: Stockholm Environment Institute.

Bugdol, M. (2008). Zarządzanie jakościq w urzędach administracji publicznej. Teoria i praktyka, Warszawa: Difin.

CAF w samorzadzie terytorialnym. (2010). Warszawa: Ministerstwo Spraw Wewnętrznych i Administracji.

Grzebyk, M. (2014). Ocena funkcjonowania wybranych urzędów gmin miejskich województwa podkarpackiego, w: Performance measurement in organizations, J. Glova, B. Gavurova (red.).

Grzebyk, M., Pierścieniak, A. (2015). Analiza instytucjonalna w urzędach gmin Podkarpacia - metodyka oceny potencjalnej sprawności instytucjonalnej urzędu gminy, Ekonomika i Organizacja Przedsiębiorstwa, 9(788): 40-49.

Grzebyk, M. (2017). Potencjał instytucjonalny administracji samorzadowej a rozwój lokalny, Rzeszów: Wyd. UR. 
Grzebyk, M., Pierścieniak, A. (2014). Wymiary zarządzania rozwojem gminy, Ekonomika i Organizacja Przedsiębiorstwa, 12(779): 43-52.

Izdebski, H. (2008). Samorząd terytorialny. Podstawy ustroju i działalności, Warszawa: LexisNexis.

Kusto, B. (2019). An assessment of the functioning of the municipal offices of Świętokrzyskie province, Prace Naukowe UE we Wrocławiu, 63(5): 152-162.

Lapsley, I. (2001). Accounting, Modernity and Health Care Policy. Financial Accountability and Management, 17(4): 331-350.

Łuczak J., Wolniak R. (2013). Ocena skuteczności zastosowania metody CAF w procesie doskonalenia administracji samorządowej, Zeszyty Naukowe Politechniki Śląskiej, Seria: Organizacja i Zarządzanie, 67: 7-18.

Mazur, S. (2004). Potencjał instytucjonalny terytorialnej administracji publicznej, ZN AE w Krakowie, 667: 57-71.

Mazur, S. (2004). Rozwój instytucjonalny. Poradnik dla samorządów terytorialnych, Kraków: Wyd. Małopolska Szkoła Administracji Publicznej AE w Krakowie.

Narbón-Perpiñá, I., De Witte, K. (2018a). Local government’s efficiency: a systematic literature review - part I. International Transactions in Operational Research, 25(2): 431-468.

Narbón-Perpiñá, I. De Witte, K. (2018b). Local government’s efficiency: a systematic literature review - part II. International Transactions in Operational Research, 25(4): 1107-1136.

Pierścieniak, A., Grzebyk, M., Mizla, M. (2018). Local government management: a view from institutional economics, Rzeszów: Wyd. URZ, Seria: Monografie i Opracowania nr 22: 156.

Pierścieniak, A., Grzebyk, M. (2015). Przygotowanie instytucjonalne urzędów gmin z Podkarpacia do realizacji strategii w latach 2014-2020, Przedsiębiorczość i Zarządzanie, XVI, 6, część I: 301-314.

Rodríguez-Pose, A. (2013). Do institutions matter for regional development? Regional Studies, 47: 1034-1047.

Stuglik, J. (2016). Wyzwania współczesnego zarządzania w jednostkach samorządu terytorialnego w obliczu zmian-analiza przypadku, Modern Management Review, XXI, 23(2): 125-138.

Truskolaski, T. (2010). Kapitał instytucjonalny w jednostkach samorządu terytorialnego, w: Proces tworzenia kapitału instytucjonalnego, K. Meredyk (red.), Białystok: Wyd. Uniwersytetu w Białymstoku.

Zawicki, M., Mazur, S. (2004). Analiza instytucjonalna urzędu gminy - poradnik dla samorzadowców, Kraków: Wydawnictwo WSAP AE w Krakowie.

Żabiński M. (2012). Samoocena systemu zarządzania w jednostkach samorządu terytorialnego: porównanie metody „Planowania Rozwoju Instytucjonalnego” i „Wspólnej Metody Oceny CAF", Zarządzanie Publiczne, 20(2): 57-76.

Žurga, G. (2018). Project management in public administration. TPM-total project management maturity model. The case of Slovenian public administration, Transylvanian Review of Administrative Sciences, 53: 144-159. 